\title{
ХРОНІЧНІ ВІРУСНІ ЗАХВОРЮВАННЯ ЯК ПРИЧИНА ЗАПАЛЬНИХ ПРОЦЕСІВ ЖІНОЧИХ СТАТЕВИХ ОРГАНІВ ТА БЕЗПЛІДДЯ
}

ХРОНІЧНІ ВІРУСНІ ЗАХВОРЮВАННЯ ЯК ПРИЧИНА ЗАПАЛЬНИХ ПРОЦЕСІВ ЖІНОЧИХ СТАТЕВИХ ОРГАНІВ ТА БЕЗПЛІДДЯ. Хронічні вірусні захворювання посідають провідне місце серед факторів виникнення запальних процесів в органах малого таза та фрормування трубно-перитонеального непліддя. У статті здійснено огляд фрахової літератури та сучасних наукових досліджень для узагальнення причин розвитку запальних захворювань органів малого таза та їх впливу на виникнення безпліддя у жінок дітородного віку. В результаті досліджень встановлено, що етіологічним фрактором запальних процесів переважно $€$ мікробні асоціації, а тривалість та перебіг захворювання характеризуються поліетіологічністю.

ХРОНИЧЕСКИЕ ВИРУСНЫЕ ЗАБОЛЕВАНИЯ КАК ПРИЧИНА ВОСПАЛИТЕЛЬНЫХ ПРОЦЕССОВ ЖЕНСКИХ ПОЛОВЫХ ОРГАНОВ И БЕСПЛОДИЯ. Хронические вирусные заболевания занимают ведущее место среди факторов возникновения воспалительных процессов в органах малого таза и формирования трубно-перитонеального бесплодия. В статье сделан обзор профессиональной литературы и современных научных исследований для обобщения причин развития воспалительных заболеваний органов малого таза и их влияния на возникновение бесплодия у женщин детородного возраста. В результате исследований установлено, что этиологическим фрактором воспалительных процессов в основном являются микробные ассоциации, а продолжительность и течение заболевания характеризуются полиэтиологичностью.

CHRONIC VIRAL DISEASES AS A CAUSE OF INFLAMMATORY PROCESSES OF WOMEN'S PELVIC ORGANS AND INFERTILITY. Chronic viral diseases occupy a leading place among the factors of inflammation in the pelvic organs and the formation of tubal-peritoneal infertility. The article provides an overview of the professional literature and current research to summarize the reasons for the development of inflammatory diseases of the pelvic organs and their influence on the occurrence of infertility in women of childbearing age. The studies found that the causative agent of inflammation are primarily microbial association, and the length and course of the disease characterized by polyetiology.

Ключові слова: вірусні захворювання, запальні захворювання органів малого таза, інфекції, що передаються статевим шляхом, трубно-перитонеальне безпліддя.

Ключевые слова: вирусные заболевания, воспалительные заболевания органов малого таза, иноекции, передающиеся половым путем, трубно-перитонеальное бесплодие.

Key words: viral diseases, inflammatory diseases of pelvic organs, infections, sexually transmitted infections, tubal-peritoneal sterility.

У сучасних умовах для хронічних запальних захворювань матки та її придатків характерні малосимптомний або безсимптомний перебіг, багатовогнищевість ураження, виражені деструктивні зміни з боку органів малого таза. Найчастіше їх причиною $є$ змішана екзогенна інфекція, при якій зростає роль аутоінфекції, в умовах ендоекологічної забрудненості організму, що виявляється ознаками ендотоксинемії, гормонального дисбалансу, кишкового і вагінального дисбіоценозу, системного і місцевого імунодефріциту й імуносупресії. Ці явища посилюються при антибіотикотерапії. Все це спонукає удосконалювати методи лікування даної патології, розробляти методи реабілітації після антибактеріальної терапії. Актуальність проблеми зростає у зв'язку з тим, що від цих захворювань страждають молоді жінки, які можуть навіть не знати про своє захворювання, але які мають реалізувати дітородну фуункцію. Саме тому проблема виявлення причин хронічних запальних хвороб органів малого таза та викликаного ними безпліддя залишається актуальною в умовах сьогодення.

Метою дослідження було вивчення хронічних вірусних захворювань як причини запальних процесів жіночих статевих органів та безпліддя.

На сучасному етапі в Україні спостерігається епідеміологічна ситуація щодо поширеності та активації сексуально-трансмісивних іноеекцій, що негативно впливає на показники захворюваності, в тому числі й на безпліддя. Ситуація з діагностикою та лікуванням запальних процесів статевих шляхів в Україні ускладнена низькою поінформованістю населення, особливо молоді. До раннього початку сексуальних відносин і наявності великої кількості статевих партнерів підштовхують вживання алкоголю, наркотиків, нездоровий спосіб життя. Запальні захворювання органів малого таза, що реєструються у 60-65 \% жінок репродуктивного віку, і виникають внаслідок хронічних інфекційних захворювань, надзвичайно несприятливо впливають на репродуктивну фрункцію жінок, обумовлюючи у них розвиток синдрому хронічного тазового болю - у $24 \%$, безпліддя - у $40 \%$, невиношування вагітності - у $45 \%$, ектопічної вагітності - у 3 \% пацієнток [1, 2].

У рамках спеціальної програми ВООЗ з репродукції людини виділено 22 фактори, здатних зумовити безпліддя жінки: сексуальна диссункція, гіперпролактинемія, органічні порушення гіпоталамо-гіпофрізарної області, аменорея 3 підвищеним рівнем фолікулостимулюючого гормону, аменорея з нормальним рівнем естрадіолу, аменорея зі зниженим рівнем естрадіолу, олігоменорея, нерегулярний менструальний цикл/ановуляція, ановуляція з регулярним циклом, вроджені аномалії розвитку статевих органів, двостороння непрохідність маткових 
труб, спайковий процес у малому тазу, ендометріоз, набута патологія матки і шийки, набуті порушення прохідності маткових труб, набуті ураження яєчників, туберкульоз статевих органів, ятрогенні фрактори, системні хвороби, негативний посткоїтальний тест, невстановлені причини [3]. На підставі існуючих уявлень виділені наступні ключові варіанти безпліддя у жінок: 1) трубна безплідність, зумовлена патологією маткових труб; 2) ендокринне безпліддя, пов'язане з розладами в діяльності системи залоз внутрішньої секреції; 3) обумовлене переважно анатомічними порушеннями в ділянці піхви і матки; 4) імунологічне, що викликається явищами сенсибілізації жіночого організму [4].

Трубне безпліддя складає 15-35 \% від усіх видів безпліддя. Більшість захворювань маткових труб виникає в результаті запальних процесів, котрі призводять до повної або часткової непрохідності маткових труб внаслідок інфрільтрації, облітерації їх стінок, згинів, обумовлених перитубарними і яєчниковими зрощеннями, функціонального порушення труб. При хронічному запальному процесі в стромі яєчника фрормується та проліферує фіброзна тканина, потовщується білкова оболонка, що призводить до порушень процесу овуляції, розвитку перитубооваріального спайкового процесу [5]. Навіть при достатній функції гіпофріза при хронічному періоофориті спостерігається зниження естрогенної активності яєчників, порушення овуляції, передчасний регрес жовтого тіла [5]. Трубна неплідність нерідко зустрічається в сполученні з ендокринними порушеннями, ендометріозом, доброякісними пухлинами матки та яєчників. Причинами анатомічних порушень можуть бути: запальні захворювання (інфекції, що передаються статевим шляхом, перитоніт, апендицит), перенесені оперативні втручання на внутрішніх статевих органах, післяпологові ускладнення, ендометріоз та ін. Етіологічним фрактором найчастіше $\epsilon$ мікробна асоціація, яка може бути представлена як абсолютними патогенами з переважно статевим шляхом передачі, так і ендогенними анаеробами і аеробами [6-8]. Мікробні асоціації сприяють кращій адаптації збудника і паразитування, підсилюють патогенність кожного збудника, їх стійкість до дії антибіотиків, що ускладнює лікування захворювання в цілому [7, 9, 10]. Згідно з результатами останніх досліджень, запальні захворювання органів малого таза мають полімікробну етіологію. Основний спектр таких захворювань представлений переважно змішаною мікробно-протозойно-вірусною інфекцією; концепція одного зі збудників втратила своє значення. Переважають збудники, що передаються статевим шляхом - Neisseria gonorrheae (25-50 \%) i Chlamydia trachomatis (25-30 \%) [11]. У жінок із ВЗОМТ також виділяють Peptococcus, Peptostreptococcus, Bacteroides, Gardnerella vaginalis, Haemophilus infl uenzae та ін. грамнегативні бактерії, Streptococcus agalactiae, Mycoplasma hominis, Mycoplasma henitalium, Ureaplasma urealyticum [11-14]. Особлива роль серед етіологічних факторів запальних процесів в органах малого таза, особливо у підлітків і жінок молодого віку, належить C. trachomatis. Так, збудник урогенітального хламідіозу Chlamydia trachomatis, $з$ одного боку, викликає запальний процес у самих маткових трубах, що призводить до їх оклюзії внаслідок деструкції фрімбрій і формування гідросальпінксу, а з іншого - сприяє розвитку запальної реакції навколо труб, що супрово- джується зменшенням їх рухливості, що перешкоджає нормальному захопленню і просуванню яйцеклітини [15]. Небезпека хламідіозу як причини безпліддя полягає в його безсимптомному перебігу у $2 / 3$ безплідних подружніх пар, що вказує лише на тимчасову рівновагу між Chlamydia trachomatis і господарем в умовах, що обмежують, але не перешкоджають розмноженню патогенного внутрішньоклітинного мікроорганізму. За морфологічними характеристиками хламідія нагадує вірус тим, що є повністю внутрішньоклітинною бактерією, а саме залежить від живильних речовин і енергії клітин господаря, та не синтезує АТФ, залишаючись енергетичним паразитом [16]. Збудник гонореї Neisseria gonorrhoeaе викликає розвиток злипливого процесу і сприяє формуванню спайок у малому тазу. Вплив мікоплазмової і уреаплазмової інфекції на прохідність маткових труб пов'язаний із їх здатністю адсорбуватися на сперматозоїдах і досягати з їх допомогою верхніх відділів репродуктивного тракту жінок. Прикріплені до клітин миготливого епітелію маткових труб, ці мікроорганізми проявляють токсичний вплив і викликають звуження або повну облітерацію труб, внаслідок чого значно порушується просування яйцеклітини в порожнину матки і виникають передумови до розвитку позаматкової вагітності. Крім того, адсорбуючись на сперматозоїдах, мікоплазми та уреаплазми зменшують їх рухливість і пригнічують їх здатність до пенетрації в яйцеклітину [15].

Роль вірусної інфекції в розвитку трубноперитонеального варіанта безпліддя вторинна і опосередкована через ослаблення місцевого імунітету 3 наступною активацією інтеркурентної бактеріальної інфекції. За деякими даними [17], найбільш різноманітна опортуністична бактеріальна і вірусна мікрофлора при трубно-перитонеальному безплідді виявляється в цервікальному каналі, у меншій мірі - в ендометрії і перитонеальній рідині, а вірусна і бактеріальна моноінсекції превалюють при переважному ураженні яєчників.

Встановлено, що гонококи, трихомонади і деякі інші збудники сексуально-трансмісивних захворювань здатні вражати неушкоджений епітелій маткових труб і ендометрія, тим самим готуючи умови для інвазії менш вірулентних анаеробів. Суперінфекція анаеробами відбувається в більш пізні терміни захворювання, тобто посилюється роль вторинного інфікування аутоінфекцією, особливо при наявності бактеріальної інсрекції піхви [18]. Транслокації аутоінсрекції сприяють сперматозоїди і трихомонади, завдяки їх адгезивним властивостям і високій рухливості [19], наявності різних протеазних активностей. Так, трихомонади володіють «клітинним роз'єднуючим фактором», за допомогою якого паразит проникає в міжклітинний простір, i, розм'якшуючи тканину, сприяє проникненню туди бактерій і формуванню вогнища запалення. Активність «клітинного роз'єднуючого фрактора» втрачається при рН нижче 4,5 і знижується в присутності р-естрадіолу, тому підвищення вагінального рН і гіпоестрогенія при трихомонозі можуть стати критичними в патогенезі запального захворювання [20].

Зросла роль мікст-інфекції, тобто бактеріально-вірусної - поєднання мікоплазмової, уреаплазмової інфекції 3 вірусом простого герпесу 1 і 2 типів, цитомегаловірусом, вірусом Епштейна - Барр та вірусом папіломи людини. Виділяють запальні захворювання органів малого таза, 
асоційовані з ВІЛ $[13,21]$. Більшість авторів відзначає, що при формуванні хронічного запального процесу у більшості хворих мікробний фрактор виникнення загострення вже не відіграє суттєвої ролі. Під впливом специфічних чинників розвивається картина, що відтворює в більшій чи меншій мірі початковий патологічний процес. Часто індуктором процесів загострення виступає герпетична інфекція [12, 13].

Важливо підкреслити, що близько 33 \% випадків хронічних запальних процесів у пацієнток із трубноперитонеальним безпліддям мають хламідійну природу $[1,15]$, тоді як при хронічному запаленні в ендометрії переважають представники умовно-патогенної мікросрлори - міко- й уреаплазми, стрепто- та ентерококи, ентеро- і коринебактерії та їх поєднання [2].

У сучасних умовах запальні захворювання органів малого таза мають деякі особливості [22]:

- рідкісний розвиток класичних фрорм захворювань;

- стерта клінічна картина як гострої, так і хронічних стадій захворювань;

- переважання хронічних процесів, а останнім часом - поява первинно хронічних захворювань;

- стійкий рецидивуючий перебіг хронічних процесів;

- найбільш часта локалізація запального процесу в придатках матки;

- рідкісне ураження параметральної клітковини;

- рідкісний розвиток гнійних процесів [11].

Виділено два клініко-патогенетичних варіанти запального процесу $[10,21]$. Для першого характерне переважання інфекційно-токсичного впливу як результату активації мікроба й активного впливу вірусно-бактеріального агента (гострий початок, біль, інтоксикація, підвищена температура тіла) - інфекційно-токсичний варіант. Другий варіант характеризується стійким больовим синдромом з ознаками порушення фуннкцій судинної, нервової та ендокринної систем [8].

Зазначимо і те, що перитонеальне безпліддя характеризується наявністю морфологічних змін стінок маткових труб, у тому числі найбільше діагностичне значення мають чергування ділянок склерозу з вогнищами дифузійної лімфрогістіоцитарної інфільтрації, роз'єднання ходу м'язових волокон, редукція капілярів і варикозне розширення венул у поєднанні з васкулітом і артеріосклерозом інших судин, дистрофія нервових волокон, деформація просвіту труби за рахунок утворення мікрокіст і дивертикулів з їх звапнінням в ендосальпінкса. Важливо відзначити, що у жінок з трубно-перитонеальним безпліддям, крім порушення прохідності маткових труб і наявності спайкового процесу в малому тазі, певну роль у розвитку інорертильності відіграють зниження гормональної фрункції яєчників і оваріального резерву, а також порушення рецептності ендометрія внаслідок формування у таких пацієнток хронічного ендометриту (XE) [17]. За даними різних авторів [23-25], частота XE у жінок із безпліддям коливається від 12,3 до 60,4 \%, будучи єдиною причиною безпліддя у 18,8 \% випадків. Крім того, в 47,3 \% випадків безпліддя, асоційованого з XЕ, виявляється і трубно-перитонеальний фактор безпліддя. За даними В. І. Краснопольського [1], спектр генітальної іноекції, виявленої при ПЛР-діагностиці виділень з цервікального каналу і порожнини матки у пацієнток з ХЕ, включає: хламідіоз - у 14,9 \%, генітальний герпес - у 33,6 \%, уреаплазмоз
- у 37, 8 \%, мікоплазмоз - у 11,6 \%, цитомегаловірусну інфекцію (ЦМВ) - у 18,9 \% хворих. 3 огляду на сучасні особливості перебігу XЕ з переважанням стертих фрорм захворювання, останнім часом все частіше основною клінічною ознакою XЕ вважають порушення репродуктивної фрункції у вигляді безпліддя, включаючи неефективність екстракорпорального запліднення (ЕК3) [15].

Основною причиною порушення анатомо-функціонального стану маткових труб є їх пошкодження і утворення спайок як між матковими трубами і органами малого таза, так і безпосередньо у фрімбріальному відділі маткової труби. У початковій стадії процес має характер катарального сальпінгіту: запалення стінки труби з гіперемією, набряком, посиленою секрецією. При прогресуванні запального процесу і виникненні запальної непрохідності маткової труби секрет, що надмірно виділяється, розтягує стінки труби, перетворюючи її в гідросальпінкс $[7,8]$. Якщо в просвіті труби накопичується гній, фрормується піосальпінкс.

Процеси, що відбуваються в запальному вогнищі, можна представити таким чином. Інфекційний агент викликає первинне ушкодження у вогнищі. Наслідком $€$ утворення і вивільнення відповідних медіаторів запалення, які здійснюють лізис мікроорганізмів, одночасно пошкоджуючи власну тканину. Вторинна альтерація спрямована на локалізацію інфекційного агента в пошкодженій ним тканині - «захист ціною ушкодження». Шляхом підвищення судинної проникності, ініціації хемотаксису лейкоцитів, активації фрібробластів автоматично втягується стандартний механізм підкріплення з боку плазми і клітин крові навколишньої сполучної тканини (явище ексудації, еміграції лейкоцитів і проліферації). Моноцити і макрофраги, головним чином, відповідальні за ранове очищення вогнища запалення, проліферацію, диференціювання і активність фрібробластів. У міру очищення вогнища запалення від інсрекційного агента і пошкодженої ним тканини ексудація і еміграція лейкоцитів стихають, посилюється проліферація і відбувається відновлення тканини або заміщення дефекту [23]. Спайки утворюються при пошкодженні вісцеральної або парієтальної очеревини, відшарувань поверхневого шару клітин мезотелію і контакту цієї ділянки з оточуючими органами і тканинами. Виникнення місцевої запальної реакції приводить до появи ексудату, багатого фрібрином, і активації процесів згортання крові. Прилягання пошкоджених поверхонь тканин створює можливість міграції фрібробластів, сприяє процесам ангіогенезу і синтезу колагену $[26,27]$.

На сьогодні встановлено, що тривалість персистування ушкоджуючого мікробного агента в ендометрії $€$ основним фактором, що визначає ступінь пошкодження тканини і вираженість функціональних порушень ендометрія. Порушення механізмів локальної резистентності сприяє персистенції мікробних агентів в ендометрії, ініціюючи хронічний перебіг запального процесу.

Таким чином, причинами хронічного перебігу запального процесу в ендометрії є:

- відсутність своєчасної діагностики і лікування;

- тривала персистенція інфекційного агента;

- тривала стимуляція імунних клітин;

- незавершеність заключної фази запалення;

- еволюція мікробних чинників з переважанням частки вірусної і умовно-патогенної мікрофрлори; 
- хронічний ендоцервіцит;

- порушення тканинного гомеостазу;

- підвищена регенерація тканини.

висновки. Первинне ураження маткових труб і тканини яєчників визначає порушення в репродуктивній функції. Особливе місце в структурі захворюваності на інфекції, що передаються статевим шляхом, займає вірусна інфекція, а саме: вірус простого герпесу і вірус папіломи людини (HPV), які значно поширені та мають високу епітеліотропність. Хронічні запальні захворювання жіночих статевих органів викликають формування спайок у малому тазі з залученням репродуктивних органів, що призводить до безпліддя, хронічного тазового болю. Важливою особливістю перебігу хронічних запальних процесів у сучасних умовах $є$ стійка тенденція процесу до стертого і малосимптомного перебігу, у зв'язку з чим ця патологія залишається недіагностованою тривалий час, що сприяє поширенню запального процесу на маткові труби. Розвиток хронічного сальпінгоофориту супроводжується заміщенням слизової оболонки маткових труб, а іноді і їх м'язового шару, сполучною тканиною, що викликає стенозування певних ділянок труб з формуванням мішечкуватих утворень (гідросальпінкс) і незворотного порушення їх фрункції. Крім того, тривалі морфологічні та функціональні зміни слизових оболонок матки і маткових труб обумовлюють наявність патологічної афрерентації в структури центральної нервової системи, що регулюють діяльність гіпоталамогіпофрізарно-яєчникового комплексу. В результаті змін у цій системі спостерігається вторинне зниження ендокринної фрункції яєчників, що, як по замкнутому колу, веде до порушення процесу овуляції і безпліддя.

ПЕРСПЕКТИВИ ПОДАЛЬШИХ ДОСЛІДЖЕНЬ ПОЛЯгають у розробці основних рекомендацій з профрілактики, лікування та реабілітації репродуктивної фрункції.

\section{СПИСОК ЛІТЕРАТУРИ}

1. Краснопольский В. И. Влияние инфекций на репродуктивную систему женщин / В. И. Краснопольский, О. Ф. Серова, В. А. Туманова // Российский вестник акушерагинеколога. - 2004. - № 5. - С. 26-29.

2. Корсак В. С. Исследование эндометрия у пациенток с трубно-перитонеальным бесплодием на этапе подготовки к ЭКО / В. С. Корсак, О. А. Забелкина, А. А. Исакова // Проблемы репродукции. - 2005. - № 2. - С. 39-42.

3. Всемирная организация здравоохранения. Департамент репродуктивного здоровья и научных исследований, 2012. - 25 с. [Электронный ресурс]. - Режим доступа к документу : http://www.who.int/reproductivehealth/ publications/ rtis/9789241503020/ru/.

4. Кулаков В. И. Современные технологии в диагностике и лечении гинекологических заболеваний / В. И. Кулаков, Л. В. Адамян. - М. : ПАНТОРИ, 2012. - 293 с.

5. Франчук А. Ю. Імунний статус організму жінок 3 хронічними запальними захворюваннями придатків матки / А. Ю. Франчук, А. В. Бойчук // Медична хімія. - 2000. - Т. 2, № 2. - C. 68-69.

6. Гомберг М. А. Ведение пациенток с воспалительными заболеваниями органов малого таза / М. А. Гомберг // Гинекология. - 2013. - Т. 15, № 6. - С. 46-49.

7. Грищенко О. В. Комплексная реабилитационная терапия у пациенток с воспалительными заболеваниями органов малого таза - залог сохранения репродуктивной функции / О. В. Грищенко, А. В. Сторчак, Т. А. Струк // Здоровье женщины. - 2011. - № 6. - С. 143-150.

8. Дубчак А. Е. Неспецифические воспалительные заболевания органов малого таза у женщин / А. Е. Дубчак, А. В. Милевский, Е. Н. Довгань // Здоровье женщины. - 2013. - № 2. - С. 51-55.

9. Агарков Н. М. Инорормативность клинических симптомов, иммунологических, гематологических показателей и проявлений эндогенной интоксикации при остром неспецифрическом сальпингоофорите / И. М. Агарков, И.В.Будник //
Журнал акушерства и женских болезней. - 2012. - Т. 61, № 4. - C. 11-15.

10. Тихомиров А. Л. Практическая гинекология : руководство для врачей / А. Л. Тихомиров, Д. М. Лубнин. - М., 2009. - С. 156-197.

11. Вдовиченко Ю. П. Воспалительные заболевания органов малого таза - комплексный подход для эфффективной терапии / Ю. П. Вдовиченко, Е. И. Гопчук // Здоровье женщины. - 2012. - № 4. - С. 102-108.

12. Коган Б. Г. Выбор антибиотиков при лечении воспалительных заболеваний женских половых органов смешанной этиологии / Б. Г. Коган, Г. Д. Гордеева // Репродуктивная эндокринология. - 2013. - Т. 6. - С. 57-62.

13. Шуршалина А. В. Оптимизация тактики ведения пациенток с воспалительными заболеваниями органов малого таза / А. В. Шуршалина // Гинекология. - 2012. - Т. 14, № 2. - C. 32-34.

14. Эмпирическая антибиотикотерапия воспалительных заболеваний органов малого таза на стационарном этапе / Е. В. Елисеева, И. П. Торговицкая, А. В. Тыртышникова [и др.] // Гинекология. - 2013. - Т. 15, № 1. - С. 12-17.

15. Клинышкова Т. В. Трубно-перитонеальное бесплодие на фоне восходящей хламидийной инфекции / Т. В. Клинышкова // Российский вестник акушера-гинеколога. - 2007. - № 2. - С. 35-37.

16. Singla M. Infectivity assays aor Chlamydia trachomatis / M. Singla, B. Bal // The Internet Journal of Microbiology. - 2005. - Vol. 2, № 2. - Available from : http://ispub.com/ IJMB/2/2/11219.

17. Забелкина О. И. Состояние эндометрия и результат ЭКО у больных с трубно-перитонеальным бесплодием : авторефр. дисс. канд. мед. наук. / О. И. Забелкина. - СПб., 2005. - 194 с.

18. Jones H. W. Novak's Textbook of Gynecology/H. W. Jones, C. S. Jones. - Baltimor, London, 1981. - P. 462-483.

19. Sachdeva R. K. Notes on Gynecology / R. K. Sachdeva. - New Delhi, 1986. - P. 289-291. 
20. Урогенитальный трихомониаз / В. М. Копылов, Е. Г. Бочкарев, В. М. Говорун [и др.] // Актуальные вопросы диагностики и лечения. - М., 2001. - 187 с.

21. Зароченцева Н. В. Воспалительные заболевания органов малого таза у женщин (обзор литературы) / Н. В. Зароченцева, А. К. Аршакян, Н. С. Меньшикова // Гинекология. - 2013. - T. 15, № 4. - C. 65-69.

22. CIN in pregnancy: antepartum and postpartum cytology and histology / L. A. Boardman, D. L. Goldman, A. S. Cooper [et al.] // J. Reprod. Med. - 2005. - Vol. 50, № 1. - P. 13-18.

23. Авраменко Н. В. Воспалительные заболевания органов малого таза у женщин как ведущий фрактор формирования трубно-перитонеального бесплодия / Н. В. Авраменко // Запорожский медицинский журнал. - 2014. - № 4. - С. 63-68.

24. Зайнетдинова Л. Ф. Оценка фрункции яичников у женщин с трубно-перитонеальным бесплодием / Л. Ф. Зайнетдинова // Вестник Южно-Уральского государственного университета. - 2009. - № 2. - С. 97-100.

25. Снарская Е. С. Саркоидоз кожи: клиника, диагностика, лечение / Е. С. Снарская // Российский журнал кожных и венерических болезней. - 2011. - № 3. - С. 36-44.

26. Грищенко О. В. Новые акценты в лечении пациенток с воспалительными заболеваниями органов малого таза / О. В. Грищенко, И. В. Лахно // Здоровье женщины. - 2013. - № 9. - С. 147-151.

27. Дергачева Т. И. Влияние различных способов введения антибиотиков на состояние лимфоидных клеток слизистых оболочек гениталий при лечении острых сальпингитов и оофоритов у женщин репродуктивного возраста / Т. И. Дергачева, А.В. Шурлыгина, В. И. Коненков // Российский вестник акушера-гинеколога. - 2013. - Т. 13, № 1. - С. 7-11. 